\title{
Distribution of ${ }^{137} \mathrm{Cs}$ and ${ }^{40} \mathrm{~K}$ in the Bottom Sediments of the Balaklava Bay (the Black Sea)
}

\author{
D. A. Kremenchutskii, K. I. Gurov ${ }^{凶}$ \\ Marine Hydrophysical Institute of RAS, Sevastopol, Russian Federation \\ 凶gurovki@gmail.com
}

\begin{abstract}
Purpose. The aim of the work is to study spatial variability of the ${ }^{137} \mathrm{Cs}$ and ${ }^{40} \mathrm{~K}$ concentrations in the bottom sediments of the Balaklava Bay, and to estimate the sedimentation rate and relative content of the biogenic fraction.

Methods and Results. The results of the ${ }^{137} \mathrm{Cs}$ and ${ }^{40} \mathrm{~K}$ concentration measurements in 5 columns of the bottom sediments sampled in various parts of the Balaklava Bay are represented. Activity of ${ }^{137} \mathrm{Cs}$ and ${ }^{40} \mathrm{~K}$ in the samples was determined by the gamma spectrometric analysis. Based on the measurement data, spatial variability of the ${ }^{137} \mathrm{Cs}$ and ${ }^{40} \mathrm{~K}$ concentration fields in the bottom sediments was studied, and the sedimentation rate was quantitatively estimated. Application of the balance equation provided quantitative estimates of the relative biogenic fraction content; its spatial variability was described. Quantitative estimates of the relationship between the biogenic fraction estimates resulted from use of the direct and indirect methods are represented.

Conclusions. According to the obtained results, the ${ }^{137} \mathrm{Cs}$ and ${ }^{40} \mathrm{~K}$ concentrations in the upper $5 \mathrm{~cm}$ layer of bottom sediments varied in space from 11 to 62 and from 155 to $562 \mathrm{~Bq} / \mathrm{kg}$, respectively. The maximum radionuclide concentrations were characteristic of the northern part of the bay, the minimum ones - of its southern part. The sedimentation average rate was $0.51 \pm 0.06 \mathrm{~cm} /$ year. Relative biogenic fraction content in the sediments varied in space from 30 to $89 \%$ and averaged $46 \pm 25 \%$. The maximum values were observed in the southern part of the bay, the minimum ones in the northern part.
\end{abstract}

Keywords: Black Sea, Balaklava Bay, bottom sediments, cesium-137 $\left({ }^{137} \mathrm{Cs}\right)$, potassium-40 $\left({ }^{40} \mathrm{~K}\right)$, sedimentation rate, biogenic fraction

Acknowledgements: the investigation was carried out within the framework of the state task on theme No. 0555-2021-0005 "Complex interdisciplinary investigations of the oceanologic processes conditioning functioning and evolution of the Black and Azov seas' ecosystems of the coastal zones" with support of the RFBR project No. 18-45-920007 "Geochemistry of bottom sediments pollutants of the Balaklava Bay (the Black Sea)".

For citation: Kremenchutskii, D.A. and Gurov, K.I., 2021. Distribution of ${ }^{137} \mathrm{Cs}$ and ${ }^{40} \mathrm{~K}$ in the Bottom Sediments of the Balaklava Bay (the Black Sea). Physical Oceanography, [e-journal] 28(2), pp. 191-204. doi:10.22449/1573-160X-2021-2-191-204

DOI: $10.22449 / 1573-160 \mathrm{X}-2021-2-191-204$

(C) D. A. Kremenchutskii, K. I. Gurov, 2021

(C) Physical Oceanography, 2021

\section{Introduction}

It is known that coastal areas are a place of active anthropogenic activity, which leads to the variation in the natural rates of geochemical processes and contributes to an increase in the pollution level of bottom sediments. Radionuclide contamination is a relatively new, but nevertheless sufficiently studied, type of environmental contamination. The intensification of industrial activity in the $19^{\text {th }}$ century led to an increase in the input of individual microelements to aquatic systems as a result of their direct discharge (local pollution) and washout by 
atmospheric precipitation (global distribution) and caused a complication of their geochemical balance and general state.

Due to its unique natural and climatic conditions and morphometric characteristics, the Balaklava Bay occupies a special place among the Sevastopol region bays. Back at the end of the $19^{\text {th }}$ century it was used as a mud treatment area. Active anthropogenic development in the second half of the $20^{\text {th }}$ century caused a change in its morphometric parameters, the intake and accumulation of a large amount of pollutants and, as a result, led to deterioration in its ecological state. As a result, medicinal clay was replaced by technogenic one. At present, the active bay use as a yacht marina maintains a high level of anthropogenic pressure on its ecosystem and may lead to deterioration in its ecological state. At the same time, the preservation of such a unique natural site is an important task for the development of the resort and recreational complex of the entire region.

The study of the Balaklava Bay bottom sediments is of an episodic nature. Modern studies of the features of spatial distribution and quantitative characteristics of the accumulation of individual fractions, organic matter, and microelements in the Balaklava Bay water area are presented in the works of Marine Hydrophysical Institute employees [1-5]. At present, much attention is paid to the pollution of bottom sediments with organic substances [2, 3] and trace metals $[3,4]$. In [2], for the first time for the Balaklava Bay water area, voltammetric profiling of the bottom sediments was carried out and the geochemical characteristics of pore waters were studied. In [5], numerical estimates of the bay water area pollution with the excessive total suspended matter, dissolved organic matter of artificial origin (an indicator of biological pollution), and petroleum hydrocarbons were obtained. According to the data of works [1, 4], the granulometric composition of bottom sediments is constantly changing. First of all, this is due to an increase in the proportion of finely dispersed pelitic silts, a decrease in the proportion of sandy and coarse shell material. The discharge of untreated domestic wastewater, industrial wastewaters, storm sewers, leaks of petroleum products from vessels based and being repaired in the bay, washout from the fields and the flow of fertilizers and pesticides with the Balaklavka River waters are the main alleged sources of pollution of the Balaklava Bay bottom sediments.

Cesium-137 $\left({ }^{137} \mathrm{Cs}\right)$ is an artificial radionuclide of technogenic origin with a half-life of 30.05 years. Its input into the Black Sea is due to atmospheric fallout and river runoff [6]. A number of works [6-13] are devoted to the study of the spatiotemporal variability of its content in the Black Sea region water and bottom sediments. This radionuclide is widely used to obtain the sedimentation rate quantitative estimates [12, 14-15].

Potassium-40 $\left({ }^{40} \mathrm{~K}\right)$ is a radionuclide of natural origin with a half-life of $1.25 \cdot 10^{9}$ years. Much attention is also paid to the study of this radionuclide [11, $12,16,17]$. The concentration of ${ }^{40} \mathrm{~K}$ in the sinking particles of lithogenic origin is approximately one order of magnitude higher than that of biogenic particles [18-22]. This feature can be used to obtain quantitative estimates of the of the biogenic component share in bottom sediments [12, 16, 17]. According to [17, 23, 24], the biogenic component of bottom sediments is a mixture of organic carbon particles, carbonate or siliceous remains of shells and skeletons of 
planktonic microorganisms. Assessment of biogenic fraction accumulation is important due to its particular sensitivity to climate change and anthropogenic impacts, and is of great importance for studying carbon cycles and various pollutants.

Based on the literature data available to the authors, it should be noted that the data on ${ }^{137} \mathrm{Cs}$ and ${ }^{40} \mathrm{~K}$ content in the Balaklava Bay bottom sediments are absent.

The purpose of this work is to study ${ }^{137} \mathrm{Cs}$ and ${ }^{40} \mathrm{~K}$ content in the bottom sediments of the Balaklava Bay, as well as to assess the sedimentation rate and the relative content of biogenic fraction.

\section{Materials and methods}

The selection and preparation of the bottom sediment samples were carried out in accordance with the regulatory documents (GOST 17.1.5.01-80; ISO 566719:2004).

The column sampling was carried out using an acrylic soil tube with an inner diameter of $60 \mathrm{~mm}$ and a vacuum seal. On board, the columns were sealed with a cork from below and transported to the laboratory. In the laboratory the columns were separated into layers of 1-2 cm thickness using a hand extruder and an acrylic ring. Further, sample preparation was carried out in accordance with the normative documents for other analyzes.

The natural moisture content was determined by the gravimetric method according to the standard method (GOST R ISO 11465-2011; introduced from 01.01.2013). After drying, the sample was crushed and homogenized. A portion of this sample with a known mass was packed into $20 \mathrm{ml}$ plastic vials for subsequent gamma spectrometric analysis.

Measurements of ${ }^{137} \mathrm{Cs}$ and ${ }^{40} \mathrm{~K}$ activity in the bottom sediment samples were carried out on a low-background gamma-spectrometer with a well-type $\mathrm{NaI}(\mathrm{Tl})$ scintillation detector. The crystal diameter is $100 \mathrm{~mm}$ and its height is $100 \mathrm{~mm}$. The diameter of the well is $40 \mathrm{~mm}$, its depth is $60 \mathrm{~mm}$. The resolution is $9 \%$ along the ${ }^{137} \mathrm{Cs}$ line with $661 \mathrm{keV}$ energy. The detector was located in a twolayer protection, the outer layer of which was formed by bricks of low-background lead $(14 \mathrm{~cm})$, the inner layer was made of old cast iron rings $(15 \mathrm{~cm})$. The measurement time of a single sample was determined based on its activity and varied within $24-48 \mathrm{~h}$ range.

The calibration of the detection efficiency of gamma quanta with different energies was carried out using certified sources supplied by the IAEA (IAEA-326, IAEA-CU-2006-03), which have a shape and size similar to the samples we studied.

The concentration of ${ }^{137} \mathrm{Cs}\left(\mathrm{C}_{137 \mathrm{Cs}}\right)$ and ${ }^{40} \mathrm{~K}\left(\mathrm{C}_{40 \mathrm{~K}}\right)$ in the bottom sediment samples was calculated using the following formula:

$$
C=\frac{N}{\operatorname{tm\varepsilon }(E) \gamma(E) K},
$$

where $C$ is a radionuclide concentration $(\mathrm{Bq} / \mathrm{kg}) ; N$ is a radionuclide photopeak area (pulses); $t$ is a spectrum accumulation time (s); $m$ is a sample mass (kg); $\varepsilon(E)$ is a registration efficiency of gamma quanta with energy $E ; \gamma(E)$ is a yield of 
gamma quanta with energy $E$ during the decay of the corresponding radionuclide; $K$ is a coefficient that takes into account the decay of a radionuclide over a period of time $(\Delta t)$ from the sampling to the beginning of its activity registration.

The estimates of $K$ were obtained by the formula

$$
\mathrm{K}=\exp (-\lambda \Delta t),
$$

where $\lambda$ is a decay constant equal to $7.31 \cdot 10^{-10} / \mathrm{s}$ and $1.741 \cdot 10^{-17} / \mathrm{s}$ for ${ }^{137} \mathrm{Cs}$ and ${ }^{40} \mathrm{~K}$, respectively.

The estimates of the minimum detectable activity were obtained according to [25]. The lower detection limit for ${ }^{137} \mathrm{Cs}$ is $4 \mathrm{~Bq} / \mathrm{kg}$, for ${ }^{40} \mathrm{~K}-30 \mathrm{~Bq} / \mathrm{kg}$.

The error in determining the activity of radionuclides is due to the statistical error of their counting in the sample $(1 \sigma)$, taking into account the static error in the background counting and efficiency calibration. In most cases, the total error did not exceed $15 \%$.

The carbonate content $\left(\mathrm{CaCO}_{3}\right)$ in the sample was determined using the weight-volume method after the decomposition of carbonates with hydrochloric acid, taking into account the methodological recommendations of the UNEP guidelines. Reanalysis of samples with a mean of $6.84 \% \mathrm{CaCO} 3$ yielded a standard deviation of $\pm 0.18 \%$ (variation coefficient $2.6 \%$ ) (UNEP/IOC/IAEA - 1995).

The organic carbon $\left(\mathrm{C}_{\text {org }}\right)$ concentration in the sample was determined by the spectrophotometric method after the organic matter oxidation with a sulfochromic mixture (GOST 26213-91; introduced from June 30, 1993).

\section{Results and discussion}

The layout of the stations is given in Fig. 1. In total, 5 columns of bottom sediments were selected: two columns in June 2015 (stations 1 and 2) and three columns in September 2019 (stations 3-5).

Columns 1 and 3-5, sampled in the northern basin of the bay at 6-9 m depths, reflect the sedimentation conditions in a semi-enclosed water area experiencing the maximum anthropogenic load. In this part of the bay, hydrodynamic processes are weakly expressed; the flux of material is determined by storm and municipal runoff. Column 2 was sampled in the southern basin at $13 \mathrm{~m}$ depth. This area is characterized by the increased hydrodynamic activity due to its proximity to the open sea. The main sources of material input are the local beach and storm runoff. According to the lithological description, the cores sampled in the northern basin are similar to each other (Fig. 2). The upper layer of $0-1 \mathrm{~cm}$ is a light-brown liquid fluff with inclusions of plant residues and shells. Below (1-11 cm layer), the sediment is represented by light-gray, gray silts, inclusions of broken shells and sand are noted unevenly, an oil smell is characteristic. Below (layer 11-19 cm), the sediment is dense, the color changes from dark gray to black, and inclusions of shell detritus are minimal. For column 2, in the surface layer $(0-5 \mathrm{~cm})$, an increased content of sandy material, individual shells, and shell detritus was noted, oil smell was absent. The content of gravel-sandy material slightly decreases with depth, and the proportion of dark gray silt increases. 


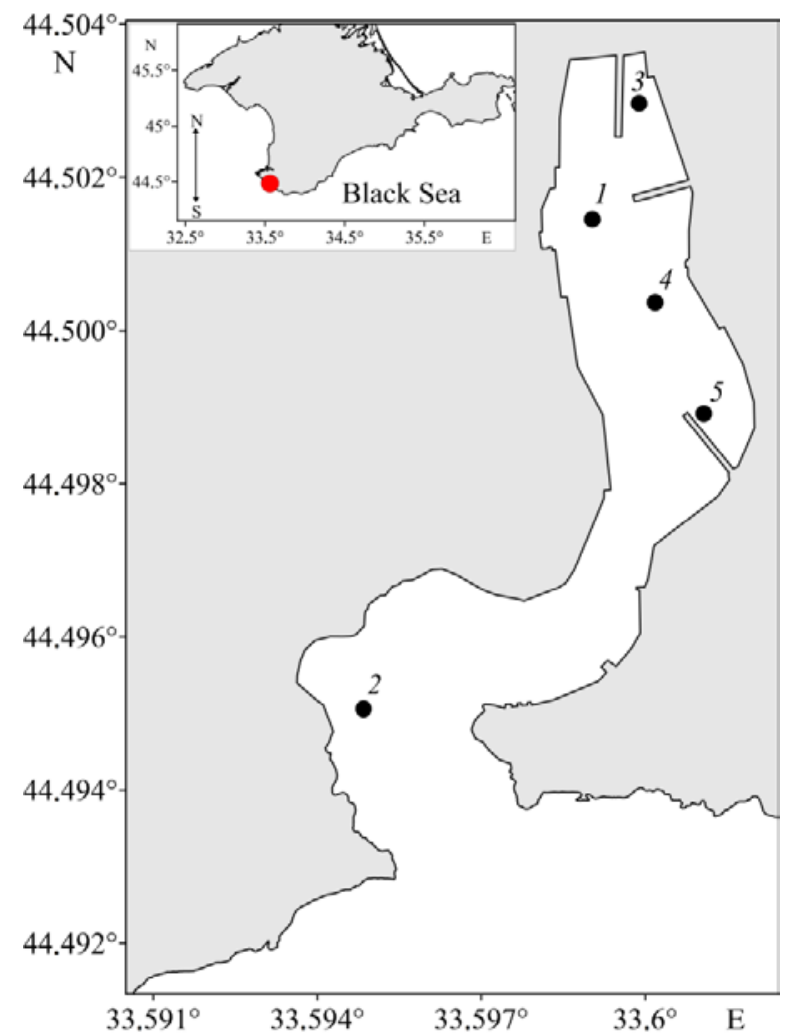

F i g. 1. Layout of the bottom sediment sampling stations
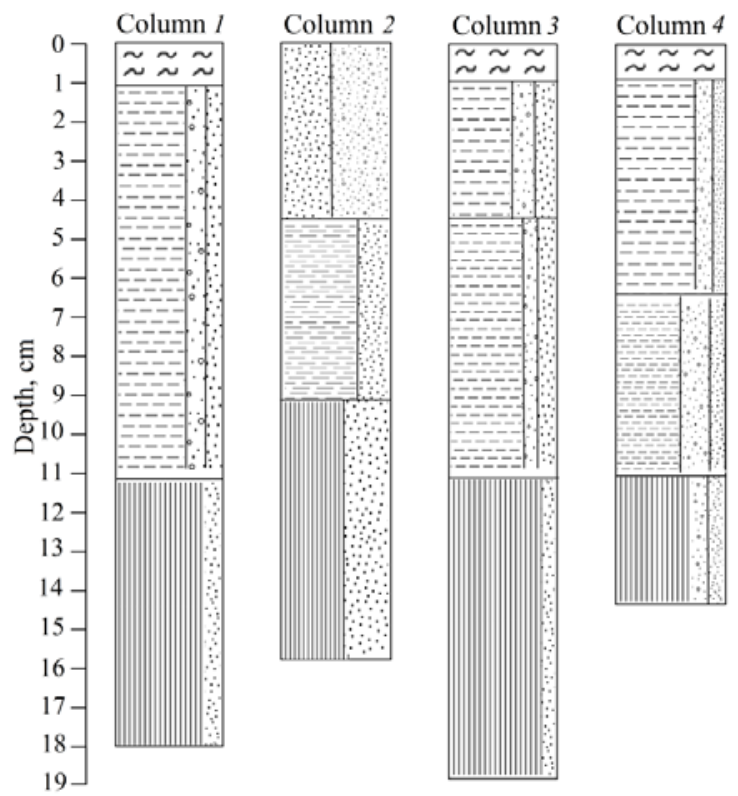

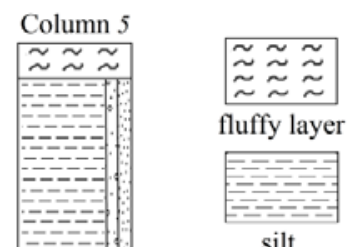

silt
light gray aleurite-pelitic
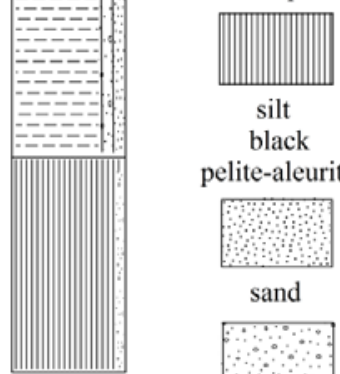

silt

black pelite-aleuritic

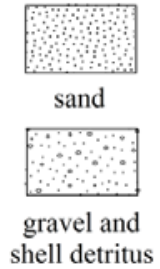

F i g. 2 Lithological scheme of sedimentary sections of the bottom sediment columns 
The average moisture content varied from $58 \%$ in $0-5 \mathrm{~cm}$ layer to $41 \%$ in $15-20 \mathrm{~cm}$ layer. It was noted that the values decrease with depth by almost one and a half times. An exception is column 4, in which the moisture content increases with depth, reaching a maximum in 5-7 cm layer, and then decreases. This may indicate gravitational sediment sliding along the slope.
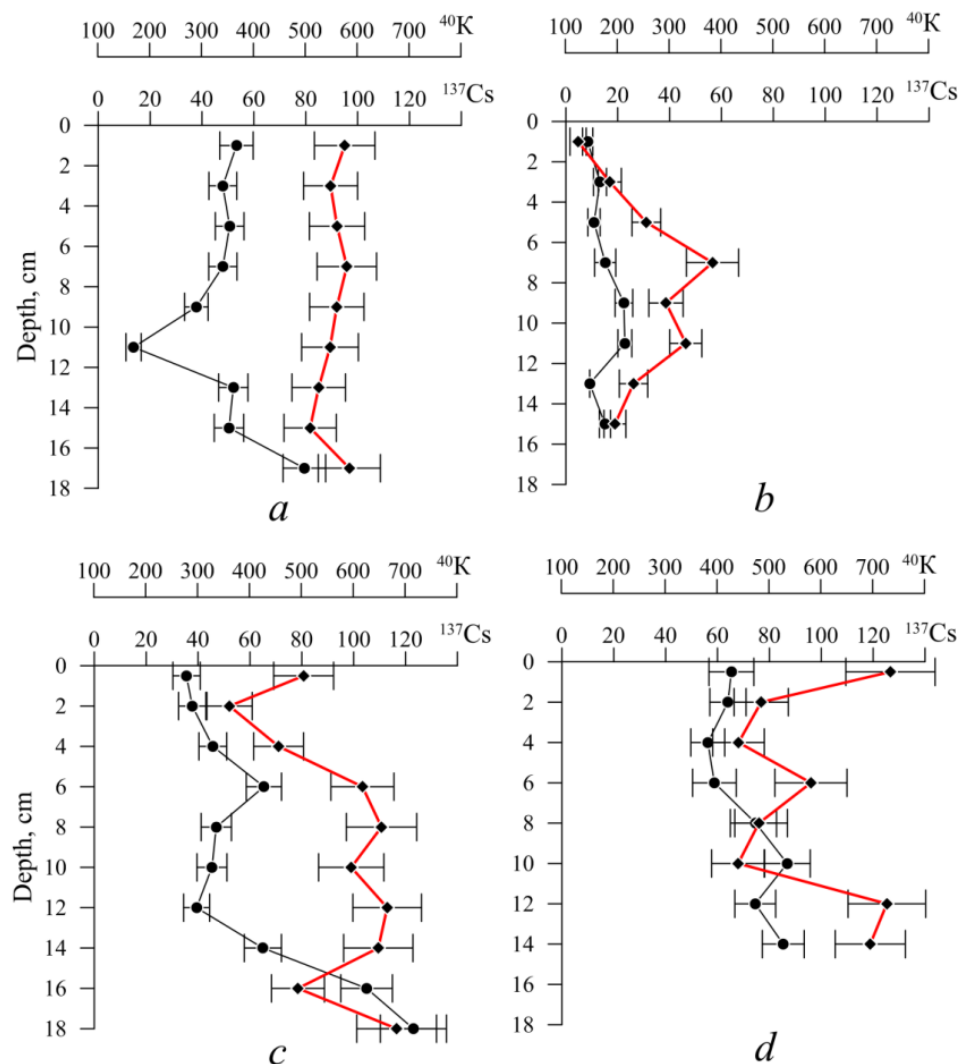

$\begin{array}{llllllll}100 & 200 & 300 & 400 & 500 & 600 & 700 & 40 \\ K\end{array}$
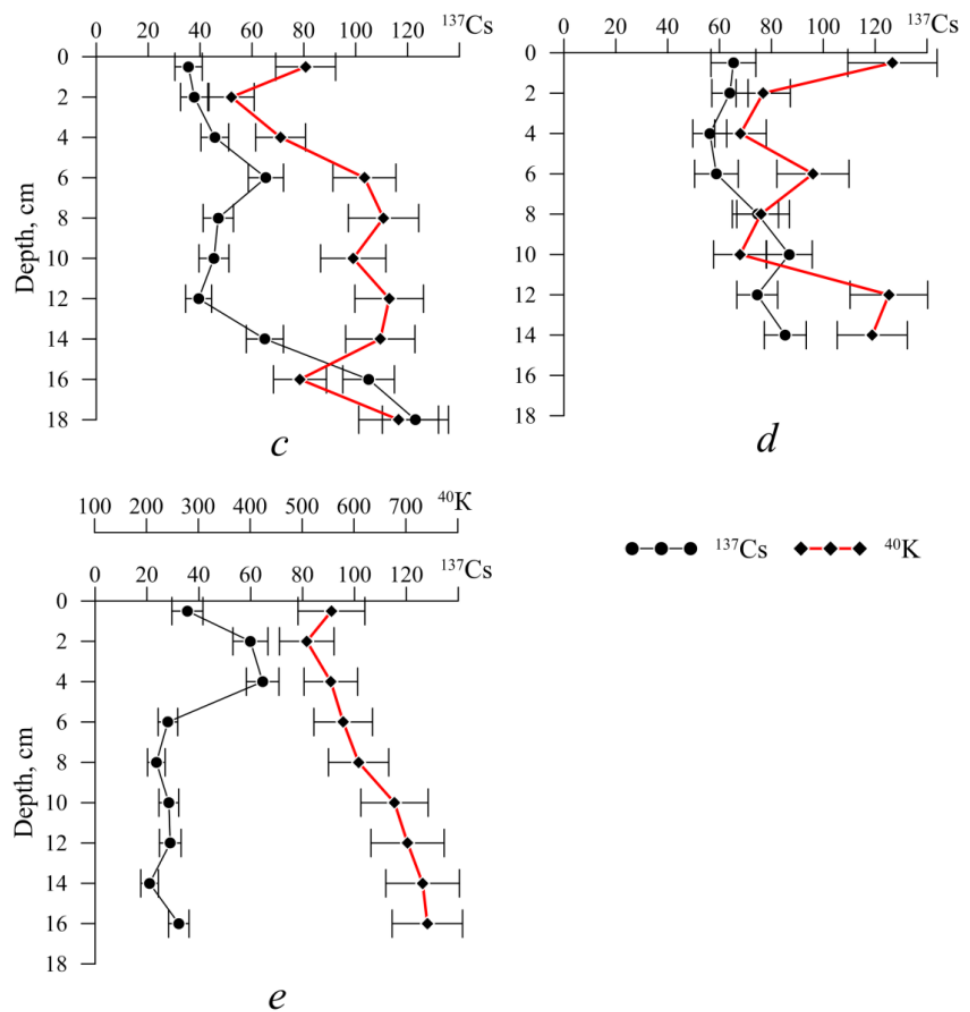

F i g. 3. Vertical distribution, $(\mathrm{Bq} / \mathrm{kg})$, of the ${ }^{137} \mathrm{Cs}$ and ${ }^{40} \mathrm{~K}$ concentrations in bottom sediments: $a-$ at station $1 ; b-$ at station $2 ; c-$ at station $3 ; d-$ at station $4 ; e-$ at station 5 
The concentration values of ${ }^{137} \mathrm{Cs}$ and ${ }^{40} \mathrm{~K}$ in the bottom sediments varied within $8.4-132.0$ and $125-742 \mathrm{~Bq} / \mathrm{kg}$ ranges, respectively. The average concentration values of ${ }^{137} \mathrm{Cs}$ and ${ }^{40} \mathrm{~K}$ were $46.5 \pm 26.2$ and $528 \pm 158 \mathrm{~Bq} / \mathrm{kg}$, respectively.

The profiles of ${ }^{137} \mathrm{Cs}$ and ${ }^{40} \mathrm{~K}$ vertical distribution concentration are complex (Fig. 3); local maxima or minima in the concentration of radionuclides, the nature of which is not obvious, are observed. Such a distribution of ${ }^{137} \mathrm{Cs}$ and ${ }^{40} \mathrm{~K}$ may indicate the presence of spatial-temporal variability in the sedimentation rate and active redistribution of bottom sediments in the water area under study.

\section{Estimation of the sedimentation rate}

The profile of ${ }^{137} \mathrm{Cs}$ concentration vertical distribution in the bottom sediments has two characteristic areas (concentration maxima) corresponding to 1963 and

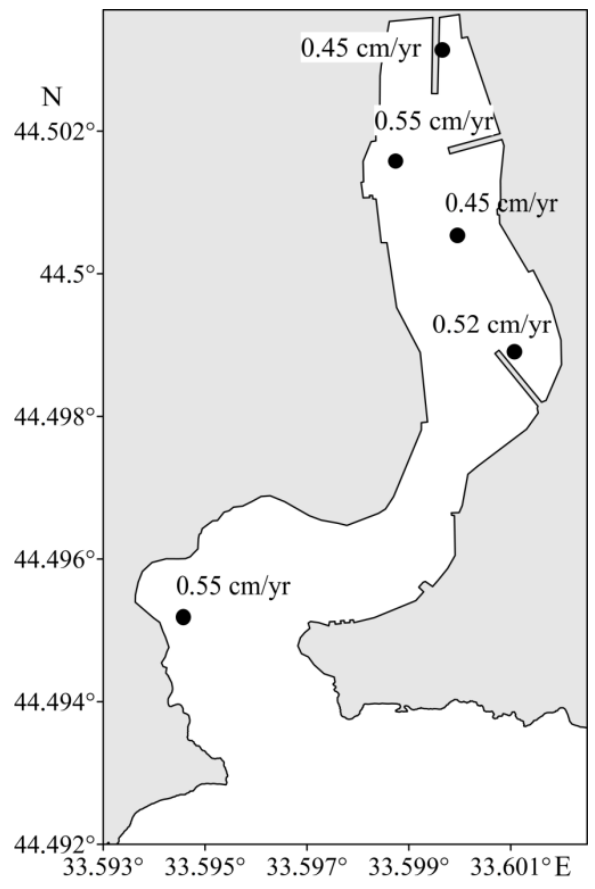

F i g. 4. Spatial distribution of sedimentation rates 1986 [12, 26]. The columns analyzed in this work are not long enough to identify the position of the nearest maximum corresponding to 1986. At the same time, the vertical profiles of ${ }^{137} \mathrm{Cs}$ clearly indicate the areas where the concentration of this radionuclide varies within an error relative to its concentration in the upper sediment layers or reveals a tendency to monotonous growth. As an example: the lower boundary of such a section in Fig. 3, $a$ corresponds to $14-16 \mathrm{~cm}$ layer; in Fig. 2, $c-$ to $13-15 \mathrm{~cm}$ layer. Based on these data, it seems possible to estimate the minimum sedimentation rate, assuming that the lower boundary of the allocated areas corresponds to 1986. The results of the estimates are presented in Fig. 4. According to the obtained estimates, the sedimentation rate varies in space within $0.45-0.55 \mathrm{~cm} /$ year range and makes up, on average, $0.50 \pm 0.06 \mathrm{~cm} /$ year. This result is in good agreement with the estimates obtained from the data on ${ }^{90} \mathrm{Sr}$ vertical distribution in 2008-2012. [12]. According to the data of this work, the sedimentation rate in the Balaklava Bay varies in space within $0.52-0.55 \mathrm{~cm} /$ year range.

\section{Spatial distribution of ${ }^{137} \mathrm{Cs}$ and ${ }^{40} \mathrm{~K}$}

The averaged characteristics of ${ }^{137} \mathrm{Cs}$ and ${ }^{40} \mathrm{~K}$ concentrations spatial distribution in bottom sediments were obtained for four intervals: $0-5,6-10,11-$ $15,16-20 \mathrm{~cm}$. It was taken into account that the first two columns were sampled four years earlier than the next three columns. For this purpose, based on the estimates of the sedimentation rates obtained in this work and presented in [12], it was assumed that the difference between the layers of the first two columns and 
the next three is $2 \mathrm{~cm}(0.5 \mathrm{~cm} /$ year $\times 4$ years $)$. In other words, $0-2 \mathrm{~cm}$ layer of the first two columns roughly corresponds to $2-4 \mathrm{~cm}$ layer of the next three columns.
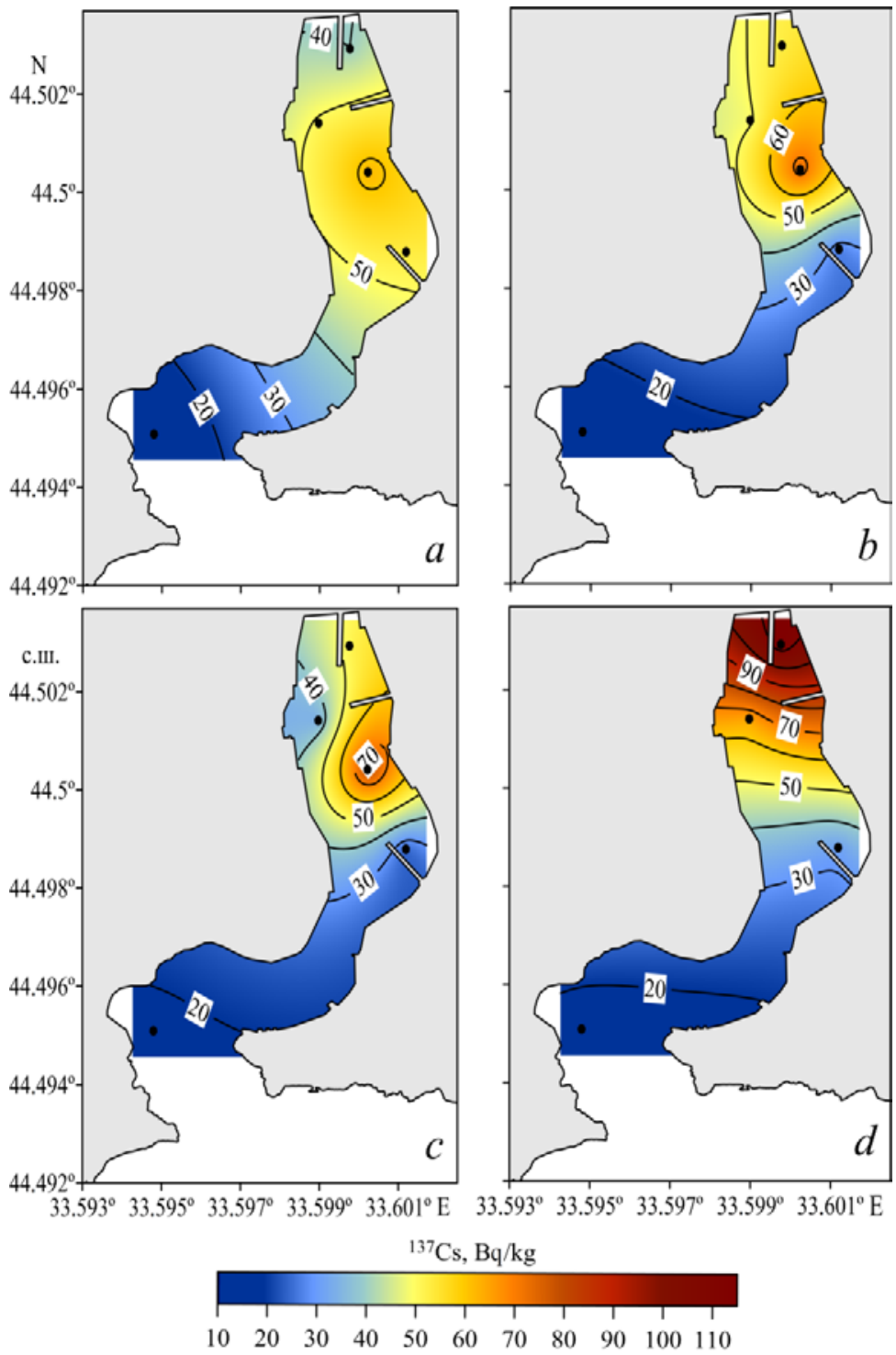

F i g. 5. Spatial distribution of ${ }^{137} \mathrm{Cs}$ concentration in the layers $0-5 \mathrm{~cm} \mathrm{(a)}, 6-10 \mathrm{~cm}(b), 11-15 \mathrm{~cm}$ (c) and 16-20 $\mathrm{cm}(d)$

According to the results obtained (Fig. 5, a), ${ }^{137} \mathrm{Cs}$ concentration in the upper layer of bottom sediments spatially varied within 11-62 Bq/kg range and averaged $43 \pm 20 \mathrm{~Bq} / \mathrm{kg}$. In the lower layers of bottom sediments (Fig. 5, $b-d$ ), an increase in the radionuclide concentration value, reaching $114 \mathrm{~Bq} / \mathrm{kg}$ at a separate station, was observed. The maximum ${ }^{137} \mathrm{Cs}$ concentration values are observed in the northern part of the bay in the entire studied range of bottom sediments, the minimum - in the southern part. Note that ${ }^{137} \mathrm{Cs}$ content in the northern part of 198 
the bay is about 5 times higher than in the southern one. The concentration of ${ }^{137} \mathrm{Cs}$ in bottom sediments and its spatial distribution depend on the levels of its activity in water and the suspended matter content $[7,15,27]$. The nature of the latter can also affect the value of the radionuclide relative content on the suspended matter

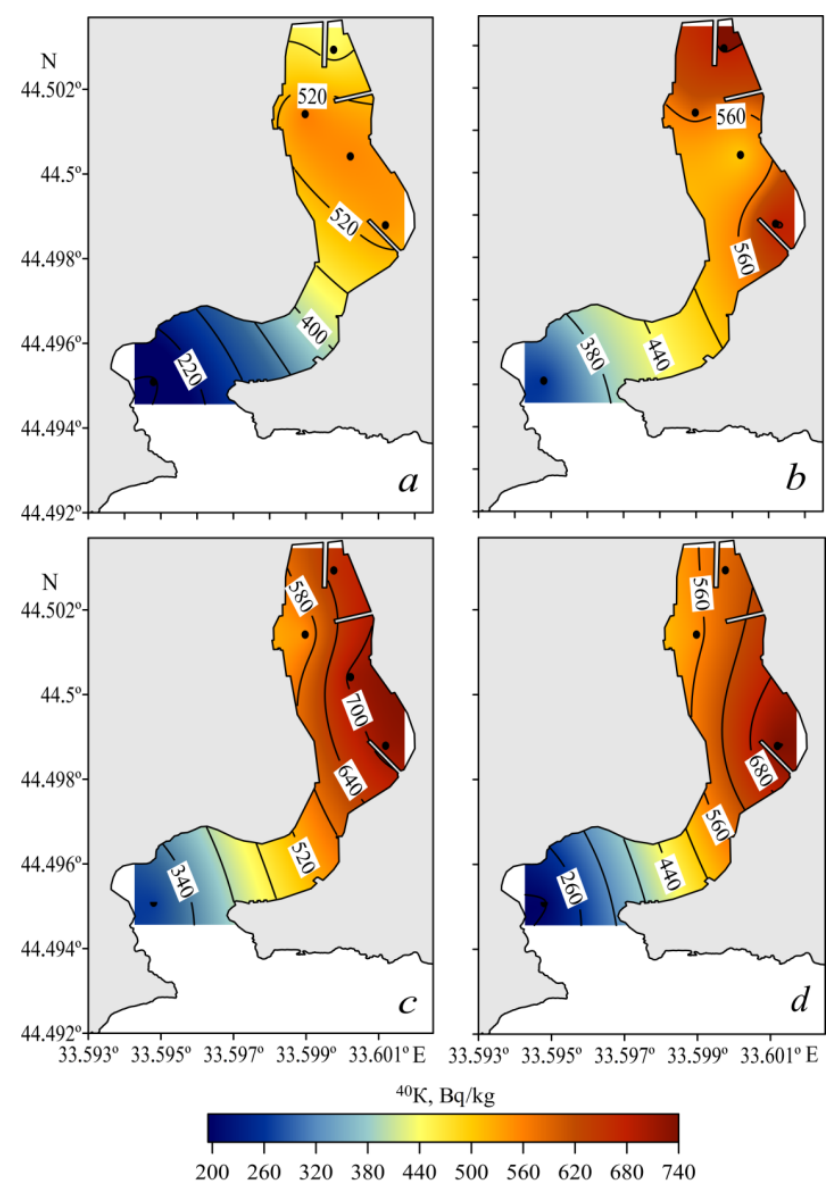

F i g. 6. Spatial distribution of ${ }^{40} \mathrm{~K}$ concentration in the layers 0-5 cm (a), 6-10 cm (b), 11-15 cm (c), 16-20 cm

and, accordingly, on its flux into the bottom sediments [7, 15, 28]. According to the data of [5], the most polluted areas of the Balaklava Bay are its innermost part and the area near the wastewater outlet at the bay exit. According to the data of optical measurements, the turbidity values, which are tens of times higher than the natural norm, as well as increased concentrations of total suspended matter and dissolved organic matter, are recorded here. The paper [29] describes the features of the in the Balaklava Bay, identified on the basis of numerical modeling results. It is noted that the presence of local eddy structures in the field of currents can lead to the emergence of areas of maximum pollution concentrations at the boundary between the central and northern parts of the bay.

The concentration of ${ }^{40} \mathrm{~K}$ in the upper layer of bottom sediments varied in space within 155-562 Bq/kg range, made up, on average, 450 $\pm 172 \mathrm{~Bq} / \mathrm{kg}$, and had a tendency to increase with depth (Fig. 6). The maximum values of ${ }^{40} \mathrm{~K}$ concentration were characteristic for the northern part of the bay, the minimum - for the southern part. As noted earlier, the concentration of ${ }^{40} \mathrm{~K}$ in bottom sediments and its spatial distribution depend on the sedimentating matter origin $[16,17]$. The increased values of ${ }^{40} \mathrm{~K}$ concentration in the northern part of the bay indicate a relatively increased proportion of the lithogenic component in the sedimentating suspension.

The similarity in the spatial distribution of the radionuclide concentration (correlation coefficient $0.51, p=0.027$ ) can be due to the fact that ${ }^{137} \mathrm{Cs}$ sedimentates mainly with the particulate matter of lithogenic origin [30, 31]. 
The obtained values of the radionuclide concentration do not contradict the literature data. According to [12], ${ }^{137} \mathrm{Cs}$ and ${ }^{40} \mathrm{~K}$ concentration levels in the Sevastopol Bay bottom sediments sampled in 2008-2012 varied in space within 70-80 and 281-702 Bq/kg range, respectively.

\section{Estimation of the biogenic fraction proportion}

In $[16,17]$, it was proposed a method that allows, based on data on ${ }^{40} \mathrm{~K}$ concentration in the bottom sediment samples, to determine the proportion of biogenic fraction $(B F, \%)$ in them using the balance equation

$$
B F=\frac{C l k_{L}-C_{\mathrm{K}}}{C l k_{L} \mathrm{~K}-C l k_{B} \mathrm{~K}} 100,
$$

where $C l k_{L} \mathrm{~K}$ and $C l k_{B} \mathrm{~K}$ are the values of potassium clarkes in lithogenic and biogenic fractions, equal to $24-26$ and $2-3 \mathrm{gK} / \mathrm{kg}$ [18-22], respectively; $C_{\mathrm{K}}$ is a potassium concentration (stable and radioactive) in the bottom sediments (in $\mathrm{gK} / \mathrm{kg})$.

It is known that the activity of $1 \mathrm{~g}$ of natural potassium is equal to $30.65 \mathrm{~Bq}$ [21]. Thus, the total potassium content in the bottom sediment samples can be obtained from the data on its concentration using the following formula:

$$
C_{\mathrm{K}}=\frac{C_{40 \mathrm{~K}}}{30.65} 100 .
$$

When making estimates, the values of $C l k_{L} \mathrm{~K}$ and $C l k_{B} \mathrm{~K}$ were assumed to be 25 and $2.5 \mathrm{gK} / \mathrm{kg}$, respectively.

According to the calculations (Fig. 7,a), the share of biogenic fraction in the upper layers of bottom sediments varied in space within 30-89\% and was, on average, $46 \pm 25 \%$. The maximum values were observed in the southern part of the bay, the minimum - in the northern one. Note that the relative biogenic fraction content in the southern part of the bay was 2-3 times higher than in the northern one. There was a tendency towards a decrease in the biogenic fraction proportion in the lower sediment layers (Fig. 7, $b-d$ ).

The proportion of biogenic fraction in the bottom sediments can also be defined as the sum of the relative values of the content of organic carbon, carbonates $\left(\mathrm{CaCO}_{3}\right)$ and silicates $\left(\mathrm{SiO}_{2}\right)$ [17]. For individual layers of the column selected at station 2 (Fig. 1), these parameters were determined and the proportion of biogenic fraction was estimated.

The analysis of the vertical distribution features of the studied parameters revealed the fact that $\mathrm{C}_{\text {org }}$ content in the surface layer is minimal $(0.48 \%)$, its concentrations increase with depth and are 2.43 and $2.46 \%$ at 7 and $11 \mathrm{~cm}$ horizons, respectively. Conversely, the carbonate content decreases with depth from $79 \%$ in $0-2 \mathrm{~cm}$ layer to $48 \%$ in $10-12 \mathrm{~cm}$ layer. $\mathrm{SiO}_{2}$ concentrations increase with depth from 14 to $21 \%$ (Fig. 8, a). 


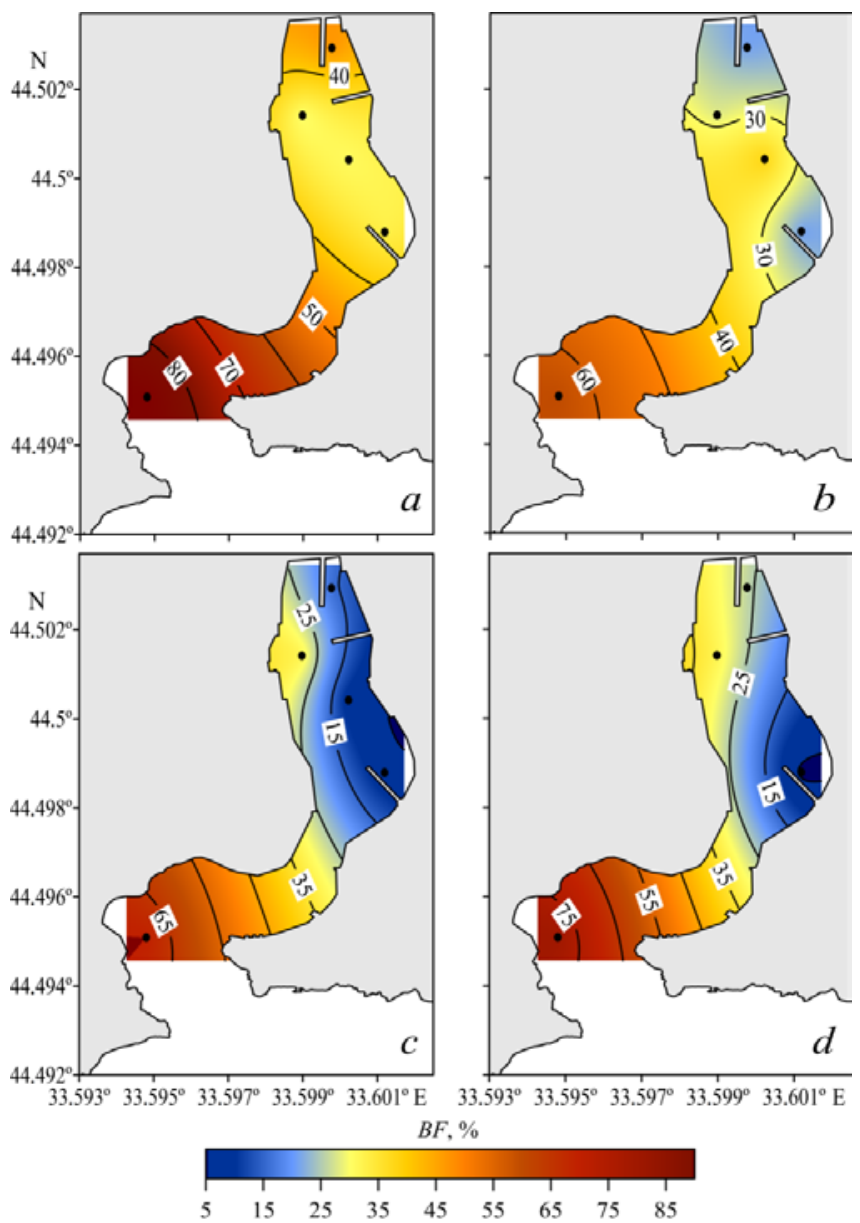

F i g. 7. Spatial distribution of the biogenic fraction in bottom sediments in the layers $0-5 \mathrm{~cm}(a)$, 6$10 \mathrm{~cm}(b), 11-15 \mathrm{~cm}(c), 16-20 \mathrm{~cm}(d)$

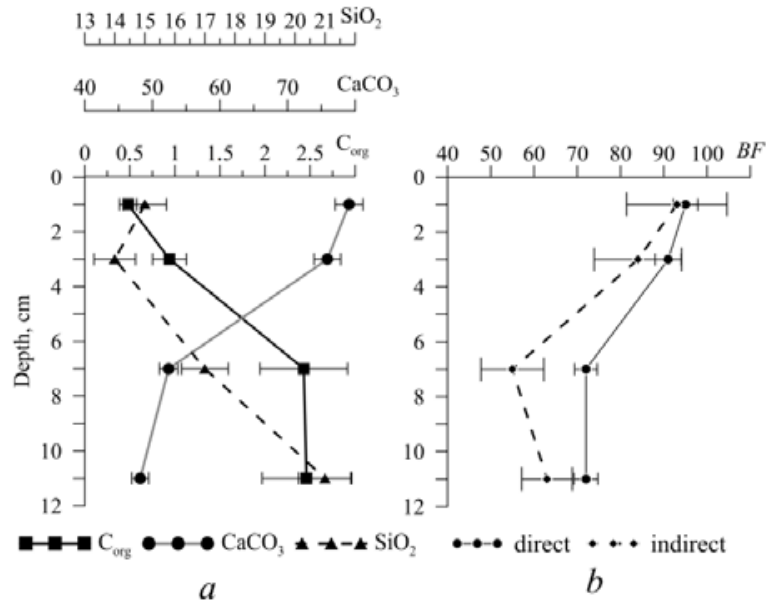

F i g. 8. Vertical distribution of the biogenic fraction (\%) in bottom sediments calculated by the direct and indirect methods 
According to the obtained results (Fig. 8, b), there is a qualitative and quantitative correspondence between the values of the biogenic fraction of bottom sediments obtained by direct $\left(\mathrm{C}_{\text {org }}+\mathrm{CaCO}_{3}+\mathrm{SiO}_{2}\right)$ and indirect (according to ${ }^{40} \mathrm{~K}$ data) methods for the upper layers of sediments. In the lower layers of bottom sediments, the estimates obtained by the indirect method differ from the results of direct measurements by, on average, $18 \pm 8 \%$.

\section{Conclusions}

According to the obtained results, ${ }^{137} \mathrm{Cs}$ and ${ }^{40} \mathrm{~K}$ concentration in the upper 5-cm layer of bottom sediments varied in space within 11-62 and 155-562 Bq/kg ranges, respectively. The average concentration values were $43 \pm 20$ and $450 \pm 172 \mathrm{~Bq} / \mathrm{kg}$ for ${ }^{137} \mathrm{Cs}$ and ${ }^{40} \mathrm{~K}$, respectively. The maximum values of the radionuclide concentration were characteristic for the northern part of the bay, the minimum - for the southern part. Such a spatial distribution of the radionuclide concentration may be due to the features of water circulation in the bay, as well as variability in the field of suspended matter concentration. There was a tendency towards an increase in the values of the radionuclide concentration with depth.

Based on the data on ${ }^{137} \mathrm{Cs}$ vertical distribution, quantitative estimates of the minimum sedimentation rate in the area under study, which were, on average, $0.50 \pm 0.06 \mathrm{~cm} /$ year, were obtained.

Quantitative estimates of the biogenic fraction proportion in the bottom sediments of the area under study were also obtained, and it was shown that it varied in space within 30-89\% range and was, on average, $46 \pm 25 \%$. The maximum values were noted in the southern part of the bay, the minimum - in the northern one. A comparison of the biogenic fraction values obtained by direct and indirect methods has been carried out, and their qualitative and quantitative correspondence in the upper layers of bottom sediments has been demonstrated.

\section{REFERENCES}

1. Orekhova, N.A., Ovsyany, E.I., Gurov, K.I. and Popov, M.A., 2018. Organic Matter and Grain-Size Distribution of the Modern Bottom Sediments in the Balaklava Bay (the Black Sea). Physical Oceanography, 25(6), pp. 479-488. doi:10.22449/1573-160X-2018-6-479-488

2. Orekhova, N.A., Ovsyany, E.I. and Tikhonova, E.A., 2019. Organic Carbon and Redox Conditions in Bottom Sediments of the Balaklava Bay. Scientific Notes of V.I. Vernadsky Crimean Federal University. Biology. Chemistry, 5(3), pp. 49-64 (in Russian).

3. Ovsyany, E.I., Kotelyanets, E.A. and Orekhova, N.A., 2009. Arsenic and Heavy Metals in the Bottom Sediments of the Balaklava Bay (Black Sea). Physical Oceanography, 19(4), 254. https://doi.org/10.1007/s11110-009-9048-4

4. Kotelyanets, E.A., Gurov, K.I., Tikhonova, E.A. and Kondratev, S.I., 2019. Pollutants in Bottom Sediments in the Balaklava Bay (the Black Sea). Physical Oceanography, 26(5), pp. 414-424. doi:10.22449/1573-160X-2019-5-414-424

5. Lomakin, P.D., Popov, M.A., Chepyzhenko, A.I. and Chepyzhenko, A.A., 2012. Estimation of Turbidity Field and Water Contamination on the Base of Hydrooptical Methods of Observation the Balaklava Bay. Ecological Safety of Coastal and Shelf Zones and Comprehensive Use of Shelf Resources. Sevastopol: MHI. Iss. 26, vol. 1, pp. 249-256 (in Russian).

6. Mirzoeva, N.Yu., Gulin, S.B. and Miroshnichenko, O.N., 2018. Strontium and Cesium Radionuclides. In: A. P. Lisitsin, Ed., 2018. The Black Sea System. Moscow: Scientific World, pp. 605-624. doi:10.29006/978-5-91522-473-4.2018 (in Russian). 
7. Fuhrmann, M., Pietrzak, R., Neiheisel, J. and Dyer, R., 1992. Partitioning of Cs-137 between Sediment and Water from the Black Sea. Chemistry and Ecology, 7(1-4), pp. 3-17. http://dx.doi.org/10.1080/02757549208055429

8. Buesseler, K.O. and Livingston, H.D., 1997. Time-Series Profiles of ${ }^{134} \mathrm{Cs}$, ${ }^{137} \mathrm{Cs}$ and ${ }^{90} \mathrm{Sr}$ in the Black Sea. In: E. Özsoy and A. Mikaelyan, Eds., 1997. Sensitivity to Change: Black Sea, Baltic Sea and North Sea. Dordrecht: Springer, pp. 239-251. https://doi.org/10.1007/978-94011-5758-2_19

9. Polikarpov, G.G., Egorov, V.N., Gulin, S.B., Stokozov, N.A., Lazorenko, G.E., Mirzoeva, N.Yu., Tereshchenko, N.N., Tsytsugina, V.G., Kulebakina, L.G., Popovichev, V.N., Korotkov, A.A., Evtushenko, D.B., Zherko, N.V. and Malakhova, L.V., 2008. Radioecological Response of the Black Sea to the Chernobyl Accident. Sevastopol: ECOSIGidrofizika, 667 p. (in Russian).

10. Delfanti, R., Özsoy, E., Kaberi, H., Schirone, A., Salvi, S., Conte, F., Tsabaris, C. and Papucci, C., 2014. Evolution and fluxes of ${ }^{137} \mathrm{Cs}$ in the Black Sea/Turkish Straits System/North Aegean Sea. Journal of Marine Systems, 135, pp. 117-123. https://doi.org/10.1016/j.jmarsys.2013.01.006

11. Chiroşca, G., Mihailov, M.E., Ţugulan, C.L. and Chiroşca, A.V., 2018. Radionuclides Assessment for the Romanian Black Sea Shelf. In: C. Finkl and C. Makowski, Eds., 2018. Diversity in Coastal Marine Sciences. Cham: Springer, pp. 221-232. https://doi.org/10.1007/978-3-319-57577-3_13

12. Mirzoeva, N.Y., Gulin, S.B., Sidorov, I.G. and Gulina, L.V., 2018. Estimation of Sedimentation and Sedimentation Rate in the Coastal and Deep-Water Areas of the Black Sea Using Natural and Anthropogenic (Chernobyl) Radionuclides. In: A. P. Lisitsin, Ed., 2018. The Black Sea System. Moscow: Scientific World, pp. 659-670. doi:10.29006/978-5-91522473-4.2018 (in Russian).

13. Dovhyi, I.I., Kremenchutskii, D.A., Bezhin, N.A., Kozlovskaia, O.N., Milyutin, V.V. and Kozlitin, E.A., 2020. Distribution of ${ }^{137} \mathrm{Cs}$ in the Surface Layer of the Black Sea in summer, 2017. Physical Oceanography, 27(2), pp. 152-160. doi:10.22449/1573-160X-2020-2-152-160

14. Drexler, J.Z., Fuller, C.C. and Archfield, S., 2018. The Approaching Obsolescence of ${ }^{137} \mathrm{Cs}$ Dating of Wetland Soils in North America. Quaternary Science Reviews, 199, pp. 83-96. https://doi.org/10.1016/j.quascirev.2018.08.028

15. Evrard, O., Chaboche, P.-A., Ramon, R., Foucher, A. and Laceby, J.P., 2020. A Global Review of Sediment Source Fingerprinting Research Incorporating Fallout Radiocesium $\left({ }^{137} \mathrm{Cs}\right)$. Geomorphology, 362, 107103. https://doi.org/10.1016/j.geomorph.2020.107103

16. Gulin, S.B., Sidorov, I.G. and Gulina, L.V., 2013. Biogenic Sedimentation in the Black Sea: Radiotracer-Derived Study. Marine Ecological Journal, 12(2), pp. 19-25 (in Russian).

17. Gulin, S.B., Gulina, L.V., Sidorov, I.G., Proskurnin, V.Yu., Duka, M.S., Moseichenko, I.N. and Rodina, E.A., 2014. ${ }^{40} \mathrm{~K}$ in the Black Sea: A Proxy to Estimate Biogenic Sedimentation. Journal of Environmental Radioactivity, 134, pp. 21-26. https://doi.org/10.1016/j.jenvrad.2014.02.011

18. Turekian, K.K. and Wedepohl, K.H., 1961. Distribution of the Elements in Some Major Units of the Earth's Crust. Geological Society of America Bulletin, 72(2), pp. 175-192. https://doi.org/10.1130/0016-7606(1961)72[175:DOTEIS]2.0.CO;2

19. Taylor, S.R., 1964. Abundance of Chemical Elements in the Continental Crust: A New Table. Geochimica et Cosmochimica Acta, 28(8), pp. 1273-1285. https://doi.org/10.1016/00167037(64)90129-2

20. Burnett, W.C., 1975. Trace Element Geochemistry of Biogenic Sediments from the Western Equatorial Pacific. Pacific Science, 29(2), pp. 219-225. Available at: http://hdl.handle.net/10125/954 [Accessed: 20 February 2021].

21. Kazansky, Yu.P., Ed., 1988. [Geochemistry of Lithogenesis under Conditions of Hydrogen Sulfide Contamination (Black Sea)]. Novosibirsk: Nauka, 194 p. (in Russian).

22. Rudnick, R.L. and Gao, S., 2003. Composition of the Continental Crust. In: H. D. Holland and K. K. Turekian, 2003. Treatise on Geochemistry. Vol. 3: The Crust. Pergamon, pp. 1-64. https://doi.org/10.1016/B0-08-043751-6/03016-4

23. Robert, C.M., ed., 2008. Global Sedimentology of the Ocean: An Interplay between Geodynamics and Paleoenvironment. Amsterdam: Elsevier Science, 487 p. https://doi.org/10.1016/S1572-5480(08)00219-4. 
24. Yücel, M., Moore, W.S., Butler, I.B., Boyce, A. and Luther III, G.W., 2012. Recent Sedimentation in the Black Sea: New Insights from Radionuclide Distributions and Sulfur Isotopes. Deep-Sea Research Part I: Oceanographic Research Papers, 66, pp. 103-113. doi:10.1016/j.dsr.2012.04.007

25. Currie, L.A., 1968. Limits for Qualitative Detection and Quantitative Determination. Application to Radiochemistry. Analytical Chemistry, 40(3), pp. 586-593. https://doi.org/10.1021/ac60259a007

26. Markelov, M.V., Golosov, V.N. and Belyaev, V.R., 2012. Changes in the Sedimentation Rates on the Floodplains of Small Rivers in the Central Russian Plain. Vestnik Moskovskogo Universiteta. Seria 5, Geografia, (5), pp. 70-76 (in Russian).

27. Smith, H.G. and Blake, W.H., 2014. Sediment Fingerprinting in Agricultural Catchments: A Critical Re-examination of Source Discrimination and Data Corrections. Geomorphology, 204, pp. 177-191. https://doi.org/10.1016/j.geomorph.2013.08.003

28. Laceby, J.P., Evrard, O., Smith, H.G., Blake, W.H., Olley, J.M., Minella, J.P.G. and Owens, P.N., 2017. The Challenges and Opportunities of Addressing Particle Size Effects in Sediment Source Fingerprinting: A Review. Earth-Science Reviews, 169, pp. 85-103. https://doi.org/10.1016/j.earscirev.2017.04.009

29. Fomin, V.V. and Repetin, L.N., 2005. Numerical Simulation of Wind Currents and Propagation of Impurities in the Balaklava Bay. Physical Oceanography, 15(4), pp. 232-246. https://doi.org/10.1007/s11110-005-0045-y

30. Sawhney, B.L., 1972. Selective Sorption and Fixation of Cations by Clay Minerals: A Review. Clays and Clay Minerals, 20(2), pp. 93-100. https://doi.org/10.1346/CCMN.1972.0200208

31. Comans, R.N.J., Haller, M. and Preter, P.D., 1991. Sorption of Cesium on Illite: Nonequilibrium Behavior and Reversibility. Geochimica et Cosmochimica Acta, 55(2), pp. 433-440. https://doi.org/10.1016/0016-7037(91)90002-M

About the authors:

Dmitry A. Kremenchutskii, Research Associate, Marine Hydrophysical Institute of RAS (2 Kapitanskaya str., 299011, Sevastopol, Russian Federation), ORCID ID: 0000-0002-8747-6612, d.kremenchutsky@gmail.com

Konstantin I. Gurov, Junior Research Associate, Marine Hydrophysical Institute of RAS (2 Kapitanskaya str., 299011, Sevastopol, Russian Federation), ORCID ID: 0000-0003-3460-9650, ResearcherID: L-7895-2017, gurovki@gmail.com

Contribution of the co-authors:

Dmitry A. Kremenchutskii - formulation of purposes and objectives of the study; analysis of literature data; determination of the ${ }^{137} \mathrm{Cs}$ and ${ }^{40} \mathrm{~K}$ concentration in bottom sediments; qualitative analysis of the results and their interpretation; discussion and analysis of the obtained results; preparation of the text of the paper

Konstantin I. Gurov - formulation of purposes and objectives of the study; analysis of literature data; determination of the concentration of organic carbon, carbonate content and silicates in bottom sediments; participation in the discussion of the paper materials; analysis and preparation of initial conclusions

All the authors have read and approved the final manuscript.

The authors declare that they have no conflict of interest. 